\title{
Causes and Consequences of the Economic Crisis in Croatia
}

\author{
Karmen Skube \\ State Administration, Karlovac, Croatia
}

\begin{abstract}
In analyzing the causes of the crisis, it is necessary to take into account certain specific features characteristic for Croatia, compared with the most of other post-communist countries. This is primarily related to the peculiarities of an inherited socialist system, and the circumstances in which the process of political and economic transformation of the Croatian society was begun. Thus, the process of multiple transition of socio-political system based on a unique model of self-management of social ownership was carried out while struggling to preserve the independence and territorial integrity of the newly established state. These factors, according to the author, are the key to understanding the present economic and social crisis in Croatia, which is generated by the current system of values. Built in the early 90's of the last century, this system is a direct consequence of the war and a badly managed transition. The imposed system of values led to a rapid disintegration of society and became an obstacle in the further process of democratization. Instead of the development of society in the direction of the rule of law and justice, "distorted" system of values paved the way for the development of systemic corruption. The cause of this problem, according to the author, is in the anomalies that occurred during the process of political transformation from the one-party system to a society based on democratic principles of pluralism and the rule of law. The result of this political transformation was the creation of a political system, which was marked by the rule of one strong political party and the weak opposition during the last decade of the 20th century. Another problem the author points to is the organizational model of the majority of newly established political parties, which is characterized by a strict hierarchical structure, with a strong leader in charge of a narrow elitist circle of people within which this program of political action was created. The end result of the implemented political transformation of the society was politocracy — an established model of the rule of political parties that functions in today's conditions. Also, the process of economic transition has enabled the emergence of plutocracy, which has in a strong symbiosis with politocracy paved the way for the practice of ruling in favor of the individual, to the detriment of the common good. According to the author's opinion, the basic requirement for Croatia to exit the economic crisis is the change in the system of values, and the prerequisite for this is the implementation of structural reforms in all fields of society-above all, the reform of the political system.
\end{abstract}

Keywords: post-communist states, self-managerial socialism, quadruple transition, stuctural reforms, merit-system in the public administration

\section{Introduction}

Political events, which marked the end of the 20th and beginning of the 21 st century, have caused a series

Karmen Skube, M.Sc. (master's degree) in the scientific field of social sciences and political sciences, majoring in international relations and national security, civil public servant in the State Administration, Karlovac, Croatia.

Correspondence concerning this article should be addressed to Karmen Skube, Bašćinska cesta 41 b, 47000 Karlovac, Croatia. E-mail: karmen.skube@gmail.com. 
of changes in national, regional (particularly European), and global terms. This was followed by the collapse of socialist ideology and it constructed socio-politic systems in the countries of Central and Southeastern Europe. As a result, decomposition of several federal states and the establishment of new international subjects, including Croatia, took place.

The process of post-communist transformation, which Croatia underwent, the same as other transition countries of Central and Southeastern Europe, was additionally burdened by the necessity of literally struggling for survival of the newly established state.

During the 90s, Croatia was forced to implement measures for transforming the inherited political and economic system, and at the same time to lead military operations in order to preserve its newly acquired political independence and territorial integrity.

According to the author of the article, exactly that period was crucial for the formation of a just system of values, which should have ensured equality before the law and equal opportunities for all members of society.

However, in terms of forming the legal and institutional framework of the state and the implementation of transition reforms, key errors, which consequences are present today, were committed.

Members of the political elite are the main culprits for the present situation. They, as the legitimate representatives of the people, working together with the holders of economic power, imposing their system of values which enabled certain individuals who were close to the structures of political power to gain wealth, and because of this, the nation was sent a message that honesty, work and education do not pay.

The newly established system of values was not based on the rule of law and the principles of justice and fairness. Established at the beginning of the 90's of the last century, this system has caused bigger and bigger division in the society and has paved the way for the development of corruption into a systematic phenomenon in the society.

Generally, when analysing the problem of corruption in society, one should take into account the fact that the main cause of corruption, which is linked to the occurrence of the first organized communities, is the lack of respect for the fundamental law of every society, especially by those in power: the separation of private and public interest, i.e., the obligations of their work for the benefit of the whole community, not just for the benefit of an individual or group (Brioschi, 2007).

However, the issue of systemic corruption is present, as is the case in Croatia, such social conditions emerges where the absence of formal rules, which will punish corrupt behavior of all members of society. Systemic corruption has characteristics of endemic beings and institutionalization, which enables corruption to be a standard, a custom, and not the exception (Stefes, 2008).

Accordingly, the basic hypothesis of the author of the article is the following: The main cause of the economic and social crisis in Croatia is the lack of implementation of democratic mechanisms in the functioning of the political system and its integral part-the party's sub-system.

The author also provides the readers with some auxiliary hypotheses:

- The overall process of transition in Croatia had a feature called "quadruple transition" (Kuzio, 2001, p. 174), which included several segments: democratisation, marketisation, state, and national-building;

- The transformation of the political system has only provided certain democratic mechanisms in the society (basic political rights and freedoms of citizens), but not the functioning of the political elite according to democratic principles; 
- The prerequisite for Croatia to exit the economic crisis is the importance of reforming the political system with the aim of democratization of the party sub-systems and the functioning of state institutions on the democratic principles of governance.

This article is divided into four thematic sections. After the introduction, in the first part of the article, the author analyzes the effects of transformation of the inherited political system, with the reference to the way political parties and state institutions function. The second part explains the negative impact of the transformation of the political system into the area of economy. In the conclusion, the author provides the readers with the prerequisitions for Croatia to exit the economic crisis.

\section{Political System - The Main Cause of a Non-functioning Legal State}

In most of post-comunist countries, transition "was primarily a political project and was carried out by political parties" (Šokčević \& Dugalić, 2007, p. 103). Transition, along together with the economic aspect, has included the political transformation of society from self-managing socialism into "liberal democracy with an installed mechanism of the defense of civil liberties and the materialization of an indepenedent judiciary" (Sung, 2004, p. 179). It is necessary to explain the concept of self-managing: It is the so-called "third" way-a model of socio-political system, neither capitalist nor socialist, which was introduced by the former Yugoslavia in the early 70's of the last century, as a form of worker self-management, after a failed attempt to turn to the market economy during the great economic reform 1965-1971 (Županov, 1989).

\section{Political Parties}

The newly established state, on the threshold of the development of a democratic society, and in the circumstances imposed by the necessity of homogenization of the public in order to defend against aggression, the present political ruling party - the Croatian Democratic Union (HDZ), led by Dr. Franjo Tuđman, was ruled with an iron fist. Fundamental rights and freedoms, the impact of opposition's political forces, civil society emergance, and free investigative journalism, as the main levers of control and supervision authorities, were largely hampered in its activities.

The preset model of organization of that political party was the same one that today still exists in most of political parties and which is characterized by strict hierarchical structure, personalization of the party, with a strong leader at the head of a narrow elitist circle of people, who create the party's program. Members of the closest political leadership of the parties are generally people "with an excess of ambition and a lack of ability" (Srića, 2013, p. 67). The practice of the leadership of the parties is to animate the party's base only periodically, mostly during election campaigns of local, parliamentary, or presidential nature, when each party is trying to jumpstart their voting machinery. After winning the elections, ordinary party members are forgotten and the leadership of the parties establishes a firm cohabitation with members of business circles, but also with all those who offer their obedience, rather than ability, in return for a political function or well-paid managerial positions in public companies. Exactly, such behavior of political parties caused the functional crisis, because they have forgotten their primary role of mediators in the communication between citizens and the state, and the political factor, which is "halfway between those who govern and are governed" (Sartori, 2002, p. 54). In other words, political parties have become self-sufficient, directing their activities exclusively toward one goal—winning the elections, after which generally followed the division of pray among their like minded and stakeholders, while the economic strategy of governing the state was thought about after winning the elections. 
The so-called moral obligation of repaying debts and favors to those who ensured the elections victory, has opened a Pandora's box of political clientelism in favor of obedient, checked individuals with questionable abilities, and against the determined educated and capable people. Consequently, this has caused a general distrust of citizens in politics and political protagonists, whose elections results over time more and more are based on all lesser turnout of citizens to the polls and the dispersal of party membership.

Strengthening of trend of public distrust in political parties had a negative consequence for the same in a very important issue - the financing of political participants. Even James Kerr Pollock, a pioneer in researching the practice of political financing in Great Britain, Germany, and France, said that "the relation between money and politics has come to be one of the great problems of democratic government" (Bradley \& Zovatto, 2014). The problem of money in politics was analyzed by Stratmann (2005, p. 143), who asked the key question of relationship between campaign candidates and donators: Do incumbents who receive money from special interest groups cater to their wishes because they received campaign contributions, or do they receive contributions because they were already committed to the interest group's point of view?

In Croatia, political parties were partly financed-funded from traditional sources: membership fees and voluntary contributions, which have melted away given the new conditions.

Law on Financing Political Activities and Election Campaigns of political participants regulates sources of financing, including those from the state budget. Due to ever more expensive political campaigns for the elections of members of the representative bodies of local and regional governments, the representatives of the Croatian Parliament, the European Parliament, and the President, new forms of financing had to be found and they soon presented themselves. Business circles and all others with extra money had a strategic plan-invest in some political parties, often in both the ruling and opposing party at the same time, hoping that their investment will pay by returning certain "favors" of the ruling party. This has further opened up space for the growing influence of money in political decision-making, with the long-term consequence of bringing in political corruption through "the front door" into the political system. A firm symbiosis of plutocracy and politocracy (Malan, 2012) paved the practice of ruling in favor of individuals to the detriment of the common good. Ferguson (2012) pointed to this problem on the example of the USA, emphasizing that in the last 30 years, the strong political power undermined the political system of the USA (including both parties: the government and academic institutions).

Due to the above mentioned, legislative framework, which should have been used to regulate the issue of financing election games at all levels of government and normal political activities, was adopted during the process of joining the European Union (EU) and the obligation of aligning the national legislation with the European legislative practice, according to the recommendations of member states of The Council of Europe for fight against corruption (GRECO). In the fourth evolution round (corruption prevention in respect of members of parliament, judges, and prosecutors) on June 25th, 2014, GRECO applauds the effort invested by Croatia in fight against corruption, but also warns that despite the invested effort, Croatian citizens do not trust the key institutions and says that "in terms of the focus of the fourth evaluation round of GRECO, in the Eurobarometer on "trust in institutions", $82 \%$ of the respondents did not trust Parliament (latest figure May 2013) and $76 \%$ expressed mistrust of the judiciary (Retrieved from http://www.coe.int/t/dghl/monitoring/greco/ evaluations/round4/GrecoEval4\%282013\%297_Croatia_EN.pdf).

A positive movement forward in reforming the political system can be seen in the current request of the civil institutions of government to introduce a form of direct democracy. Under the influence of the above 
mentioned, the Croatian Parliament passed the Law on Amendments and the Law on Election Policies for the members of the Croatian Parliament in 2015, which determines the possibility of choosing deputies by proportional representation and preferential ballot (the right to one preferred voice). The experience of Croatian citizens during the two conducted election processes for members of the European Parliament triggered the discussion. It is expected that changes to the law will be voted by the end of this year, with the intention to enforce the law by the next parliamentary elections in 2015 .

\section{Principles of Functioning of Good Governmental Institutions-Comparison With the Croatian Political Practice}

Usually, to rule in the general interest of the people means that you have to obey certain democratic principles, which the political elite in Croatia ignores, on all three levels of government. According to Fukuyama (2005), good government should work in accordance with certain principles. Otherwise, failure to comply with the fundamental postulates of the reign of good government - the principles of accountability, efficiency, and transparency, makes room for kakistocracy:

A political socio-economic regime is based on plundering of the state's and the people's assets and property through merging the political leadership and the criminal oligarchic structures, under the guise of the democratisation of the society, introduction of market economy, and the rule of law and priority of human rights and fundamental freedoms. The major features of kakistocracy are: usurpation of power through unfair and falsified elections; growing polarization of the society; impoverishment of the bulk of population and enrichment of a handful of nouveaux riches; selling out to the foreign capital the economic and other assets based on clan interests; and thriving corruption and the rule of lawlessness. (Abadjian, 2010, p. 157)

One of the basic principles of good ruling is the principle of the responsibility of members of the political elite for their own actions. The essence of this responsibility is the necessity of separating private from public interest when holding political functions. The problem of conflict of interest ${ }^{1}$, reflected in public office holders obtaining personal gain and working against the interests of the common good, is very complex. To adequately prevent it, the term needs to be defined precisely.

Organization for Economic Cooperation and Development (OECD) gives three types of conflict of interest:

- conflict of interest (actual): a conflict between the public duty and private interests of a public official, in which the public official has private-capacity interests which could improperly influence the performance of their official duties and responsibilities;

- conflict of interest (apparent): an apparent conflict of interest which can be said to exist where it appears that a public official's private interests could improperly influence the performance of their duties, but this is not in fact the case;

- conflict of interest (potential): a potential conflict which arises where a public official has private interests so that a conflict of interest would arise if the official were to become involved in relevant (i.e. conflicting) official responsibilities in the future (OECD, 2003).

Also, the Committtee of Ministers defines conflict of interest as: (1) Conflict of interest arises from a situation in which the public official has a private interest to influence or appear to influence the impartial and

\footnotetext{
${ }^{1}$ In the Dubrovnik Republic (1358-1808), it was founded in southern Croatian, in the area of today's city of Dubrovnik and its immediate mainland and island surroundings, as a reminder to Dubrovnik officials of the obligation to act in accordance with the public interest. At the entrance to the great hall of duke's court, it stood inscription: "Obliti privatorum, publica curate" (forget your own interests and care for the common good).
} 
objective performance of his or her official duties; (2) the public official's private interest includes any advantage to himself orherself, to his or her family, close relatives, friends, and persons or organisations with whom he or she has or has had business or political relations. It includes also any liability, whether financial or civil, relating to (Retrieved from http://www.coe.int/t/dghl/monitoring/greco/documents/Rec\% $282000 \%$ 2910_EN.pdf).

Furthermore, it is necessary to distinguish an important fact for establishing an effective legal mechanism for its prevention - conflict of interest cannot automatically fall under corruption, but it may pose a risk for committing a corruption related crime. Therefore, if it is not identified and appropriately solved in a timely fashion, it can become a major source of political corruption. Exactly because of that, the EU's politics is aimed at stopping and preventing corruption in the most sensitive segments of society-political parties and public sector. It is estimated that the EU loses 120 billion euro per year to corruption (Popescu, 2014) and that it is focused on the necessity of enforcing law measures and monitoring mechanism, which would be used to periodically evaluate the effort of the EU members in the fight against corruption. The first EU Anti-Corruption Report was released in 2014, published on February 3rd, 2014 (Retrieved from http://ec.europa.eu/dgs/ home-affairs/e-library/documents/policies/organized-crime-and-human-trafficking/corruption/docs/acr_2014_e n.pdfhttp://ec.europa.eu/anti-corruption-report).

In general, looking at current results of the measures taken, the Southeastern European countries, including the region's non-EU members, are involved in the fight against corruption, but, in general, they are not keeping pace with other European countries, mostly in enforcement (Popescu, 2014). Also, identifying corruption as a disease of global society realizes the necessity of international cooperation in the fight against corruption and stresses that synchronized legislation, information sharing, and cooperative enforcement are essential (Popescu, 2014). In the already mentioned EU Anti-Corruption Report from 2014, the data from the 2013 Eurobarometer Survey on Corruption were published for all members of the EU, according to which the $94 \%$ of the Croatian respondents believe that corruption affects their daily lives (EU average: $26 \%$ ), $89 \%$ of the respondents say that bribery and the use of connections are often the easiest way to obtain certain public services in Croatia (EU average: 73\%) (Retrieved from http://ec.europa.eu/dgs/home-affairs/what-we-do/ policies/organized-crime-and-human-trafficking/corruption/anti-corruption-report/docs/2014_acr_croatia_chapt er_en.pdf).

The principle of the effectiveness of governmental institutions is measurable through the evaluation of the quality of public services and the operation of the civil service. These officials have an obligation to serve the interests of citizens and not to serve their own needs. The efficiency of state institutions is evaluated in relation to the quality of legislation, which the same create and enforce. One of the common problems of states in transition is a problem of public administration as "the totality of the legal and material activities, which are the responsibility of the public authorities and whose purpose is to satisfy the public interest" (Šimac, 2002, p. 31), which in the former socialist system was a place of mass employment of citizens on the principle of political correctness, family or native connections, and bribing. Criteria in evaluating skills, education, and competence of civil servants and employees were not essential for obtaining a job. This fact is the main cause of inefficiency, ineffectiveness, inertia of the bureaucratic machinery in Croatia, which, in terms of market economy, is becoming one of the main obstacles for economic development of the country. The inherit system of public administration should have been reformed, according to the principle of merit-system at the very beginning, which follows strict criteria when it comes to hiring and advancement. However, over the past 20 
years, meritocracy (Krauze \& Slonczynski, 1985) in the bureaucratic machinery and the society in general was replaced with mediocrity. The workplace has become a purely social or political category. The entire public administration is largely a political issue, a common practice of all previous governments, whether left or right centered, and was reduced to a common denominator: to hire staff that would suit them. Over time, the bureaucratic machinery has become a nursery of unskilled public servants, who were at each moment "able to disable the capable" (Srića, 2013, p. 111).

The principle of transparency in political action ensures public control and evaluation of public authorities. Transparency contributes to creating the conditions for a broad involvement of citizens in policy-making processes. Making decisions solely within the political elite, without taking into account public opinion, and without liability, does not ensure the efficiency of state institutions, but opens the possibility for power abuse. The media has a major role in encouraging transparency of government. In democratic societies, the media is referred to as the fourth pillar of government. Investigative journalism and civil society institutions have a special role in the whole process. In recent years, more precisely since 2008, when the former Croatian Prime Minister, Ivo Sanader suddenly, without an explanation, resigned from his post, the role of media and civil society has been put under the limelight. It is necessary to clarify that the mentioned year was a turning point for the intense fight against corruption, which was one of the basic requirements for entering the EU. Among the first suspects for abuse of position and power, and corruption, was the former Prime Minister Sanader. His case triggered significant progress in the work of the media and civil society organizations. Looking at present affairs of political officials, who have engaged in political corruption and clientelism, it can be seen that very often the State Attorney's Office initiated proceedings only after several newspaper articles were published or an intensive action of some non-governmental organizations was taken. This practice leads to the conclusion that the Croatian public is becoming aware of its natural role of a supervisor of the government that it decided to trust.

Generally, the issue of political corruption and clientelism is current in all societies, regardless of the level of democracy and the recognition of these phenomena, these notions should be distinguished. Lemarchand and Legg (1972) gave one explanation of the term clientelism:

Unlike "class" and "ethnicity", both of which are group phenomena, clientelism refers to a personalized and reciprocal relationship between an inferior and a superior, commanding unequal resources; moreover, in contrast with the "ideal type" of bureaucratic relationship, the norms of rationality, anonymity, and universalism are largely absent from the patron-client nexus. (p. 151)

There are different definitions of the term "political corruption", which can be classified according to certain criteria (Peters \& Welch, 1978; Scott, 1972). Nye (1967) gave the definition of political corruption based on legalistic criteria, saying that the political action is corrupt, when it deviates from the formal duties of a public role (elective or appointed), because of private-regarding (personal, close family, and private clique) wealth or status gains, or violates rules against the exercise of certain types of private-regarding influence.

\section{Consequences of a Non-functioning Legal State on the Economic System}

A political system is the foundation of any societies. However, if it is not built on democratic principles, it will start to produce the so-called "butterfly effect" (Gojanski et al., 2010). Its negative impact will be reflected in all other areas of society, especially in the economic system. 
The consequences of conversion and privatization (Gregurek, 2001) carried out in Croatia have changed the structure of the society, causing deep divisions and impoverishment, which then resulted in formation of the opinion of the vast majority of the population that these two processes have destroyed the Croatian economy and society.

However, the fact is that in the transition process reforms of the economic and political agenda should have been carried out, but they were carried out in the wrong direction.

Specifically, conditions for a functioning legal state should have been ensured through creating legislative and institutional frameworks that would then serve as a basis for implementation of reforms in the economic system.

Also, the processes of conversion and privatization were supposed to go in the direction of changing the state into social ownership, and after into private ownership, they had to be based on previously determined overall strategy for the development of the Croatian economy.

Furthermore, the whole reform process should have been monitored and a number of activities of holders of political power, aimed at changing their own consciousness and the consciousness of citizens, which was rebuilt through decades in a socio-political system of completely different values from those that was automatically imposed through the reforms. The way living up to then had been in accordance with the principles of egalitarianism, state paternalism, low levels of political participation of citizens, and the reforms leaving a deep mark in the nation's perception, so the changes were necessary.

However, since the political elite had the absolute, uncontrolled power, it willingly reassigned national wealth, taking it away from those who created it and practically giving it away to "reverse owners" (Lasić, 2000, p. 110), who lacked the knowledge and experience in managing the given enterprises. Their main qualifications consisted of connections with the centers of political power. It can be concluded that the result of politicized privatization is today visible through the general inefficiency of the economy, which is characterized by the existence of gray zones of economy, rising number of the unemployed, reduction, or to be more precise, lack of foreign investment, and brain-drain (Schneider, 2003).

According to the European Commission economic forecast (Autumn, 7/2014) for the period from 2014 to 2016, Croatia will remain in recession for the sixth consecutive year, with the increase in the debt-to-GDP ratio from $81.7 \%$ in 2014 and further growth to $84.9 \%$ and $89.0 \%$ in 2015 and 2016 . At the same time, the unemployment rate for this and next year is estimated at $17.7 \%$, with a slight decline to $17.3 \%$ in 2016 . The European Commission's warning points out the necessity for rapid structural reforms, and if the Croatian government continues to delay the same, further economic decline projections will be much worse (Retrieved from http://www.ec.europa.eu/economy_finance/eu/forecasts/2014_autumn_forecasts_en.htm).

Also, according to the latest European Commission economic forecast (Spring, 2/2015), it predicts the GDP growth in the euro zone to $1.5 \%$ in 2015 and $1.9 \%$ in 2016, and for the whole EU it predicts the GDP growth of $1.8 \%$ in the current year and $2.1 \%$ in 2016 .

According to the single-estimate for each EU member state, in 2015, only Cyprus will have a reduction of real GDP by $0.5 \%$. Croatia follows with an increase of GDP this year to $0.3 \%$. Comparing the predictions regarding GDP growth in 2015 for Croatia with other countries in transition (Slovakia: growth of 3.0\%; UK: growth of $2.3 \%$; Bulgaria: growth of $1.0 \%$; Czech Republic: growth of $2.5 \%$; Hungary: increase of $2.8 \%$; Poland: growth of $3.3 \%$; and Romania: growth of $2.8 \%$ of GDP), it can be seen that Croatia is in the group of countries (Greece: growth of $0.5 \%$ or Italy: growth of $0.6 \%$ of GDP) which has only started recovering form the recession . 
Also, while at EU level, it forecasts further recovery in the labor market, with a predicted unemployment rate of $9.6 \%$ in 2015 (the average of the euro zone is $11.0 \%$ ), Croatia will have the unemployment rate of $17.0 \%$.

Furthermore, the European Commission forecasts for Croatia the deficit in 2015 of 5.6\% of GDP (a slight decrease compared to the $5.7 \%$ in 2014), while the forecast of growth of public debt during 2015 and 2016 is predicted at more than $90 \%$ GDP.

According to estimates of the European Commission, the positive economic developments in Croatia in 2015 are largely the result of the recovery of other member states, in particular Croatian trading partners and lower oil prices on the world market, while a small part of the result are in the sphere partly enforced reforms and in the field personal income taxation (Retrieved from http://www.ec.europa.eu/economy_ finance/eu/forecasts/2015_spring_forecast_en.htm).

\section{Conclusions}

Where is Croatia today? If comparing the period before Croatia has entered the EU to the present day, during the past two years, as a member of the EU, Croatia has regressed in many different segments. According to the author's opinion, this is particularly evident in the attempts of implementation of democratic mechanisms under which political institutions should function.

The greatest absurdity lies in the fact that Croatia has met all the prerequisites for entering the EU, in terms of implementing the EU legislation, since the moment it joined the EU most of the legislation has not been enforced.

The above mentioned reasons point to the lack of political will of any previous governments, either left or right centered, to enforce key reforms, above all, the reform of political system which is at the moment the main generator of the general crisis in the Croatian society.

However, certain positive developments can be seen in terms of increasing pressure from the public, non-governmental organizations, the media, and the political institutions to introduce certain forms of direct democracy (the mechanism of decision-making on issues of national importance through referendums and preferential voting).

Society, which is webbed with systemic corruption, political clientelism, and conflict of interest of members of the government, demands structural reforms from which a new system of values will have to be built and which will cancel out the current rule of mediocracy in favor of meritocracy.

Structural reforms must be implemented in order to achieve efficient, transparent, and effective functioning of political institutions. Also, reforms should be aimed at strengthening public awareness of their social responsibilities, in the sense that it must be reduced not only to the voting machinery, but also to become a powerful controller and corrective of the holders of political power.

\section{References}

Abadjian, V. (2010). Kakistocracy or the true story of what happened in the post-Soviet area. Journal of Eurasian Studies, 1, 153-163.

Bradley, A., \& Zovatto, D. (2014). Financing of political parties in the European Union (EU) and Latin America. Retrieved from http://www.idea.int/resources/analysis/upload/EU-LAC-FPP.pdf

Brioschi, C. A. (2007). A brief history of corruption, from antiquity to the present day, talk Croats from pirate country to independence. Zagreb: Publisher Mate d.o.o..

Committee of Ministers. (2000). Recommendation No. R (2000) 10 of the Committee of Ministers to member states on codes of conduct for public officials. Retrieved from http://www.coe.int///dghl/monitoring/greco/documents/Rec\% 282000\%2910_EN.pdf 
Council of Europe., \& Group of States against Corruption. (2014). Fourth evaluation round, corruption prevention in respect of members of parliament, judges and prosecutors, evaluation report Croatia. Retrieved from http://www.coe.int/t/dghl/monitoring/greco/evaluations/round4/GrecoEval4\%282013\%297_Croatia_EN.pdf

European Commission. (2014). European economic forecast (Autumn, European economy 7/2014). Retrieved from $\mathrm{http} / / / \mathrm{www} . e c . e u r o p a . e u /$ economy_finance/eu/forecasts/2014_autumn_forecasts_en.htm

European Commission. (2014). Report from the Commission to the Council and the European Parliament, EU anti-corruption report. Retrieved from http://ec.europa.eu/dgs/home-affairs/e-library/documents/policies/ organized-crime-and-human-trafficking/corruption/docs/acr_2014_en.pdfhttp://ec.europa.eu/anti-corruption-report

European Commission. (2014). Report from the Commission to the Council and the European Parliament, anti-corruption report; Anex-Croatia to the EU anti-corruption report. Retrieved from http://ec.europa.eu/dgs/home-affairs/what-we-do/policies/ organized-crime-and-human-trafficking/corruption/anti-corruption-report/docs/2014_acr_croatia_chapter_en.pdf

European Commssion. (2015). European eonomic forecast (Spring, European economy 2/2015). Retrieved from http://www.ec.europa.eu/economy_finance/eu/forecasts/2015_spring_forecast_en.htm

Ferguson, C. H. (2012). Predator nation: Corporate criminals, political corruption and the hijacking of America. New York: Crown Publishing Group.

Fukuyama, F. (2005). Izgradnja države, Vlade i svjetski poredak u 21 stoljeću (Building a state, governments and the world order in the 21st century). Zagreb: Biblioteka Izvori.

Gojanski, D., Gajski, L., Škaričić, N., Sladoljev, S., \& Marušić, M. (2010). Korupcija u hrvatskom zdravstvu (Corruption in the Croatian healthcare system). Osijek: Fond Hipokrat-Zaklada Slagalica.

Gregurek, M. (2001). The degree and the effects of privatisation in Croatia. Ekonomski pregled, 52(1-2), 155-188.

Krauze, T., \& Slonczynski, K. M. (1985). How far to meritocracy? Empirical tests of a controversial thesis. Social Forces Volume $63(3), 623-642$.

Kuzio, T. (2001). Transition in post-communist states: Triple or quadruple? Politics, 21(3), 168-177.

Lasić, V. (2000). The concept of privatisation model in Croatia. Ekonomski pregled, 51(1-2), 107-117.

Lemarchand, R., \& Legg, K. (1972). Political clientelism and development: A preliminary analysis. Comparative Politics, 4(2), 149-178.

Malan, K. (2012). Politocracy: An assessment of the coercive logic of the territorial state and ideas around a response to it. Pretoria: Pretoria University Law Press.

Nye, J. S. (1967). Corruption and political development: A cost-benefit analysis. American Political Science Review, 61, 417-427.

Organisation for Economic Co-operation and Development. (2003). Managing conflict of interest in the public service: OECD guidelines and country experiences. Retrieved from http://www.oecd.org/gov/ethics/48994419.pdf

Peters, J. G., \& Welch, S. (1978). Political corruption in America: A search for definitions and a theory, or if politilac corruption is in the mainstream of Ameriacan politics, why is it not in the mainstream of American politics research? The American Political Science Review, 72(3), 974-984.

Popescu, A. I. (2014). Corruption in Europe: Recent developments. CES Working Papers, 6(2A), 150-160.

Sartori, G. (2002). Stranke i stranački sustav (Political parties and systems in political parties). Zagreb: Analitički okvir.

Schneider, F. (2003). The size of the gray economy and the labor force in the informal economy in 22 transition countries and 21 country OECD: What do we really know? Financial Theory and Practice, 27(1), 1-29.

Scott, J. C. (1972). Comparative political corruption. Englewood Cliffs: Prentice-Hall, Inc..

Šimac, N. (2002). Europski principi javne uprave: od vladanja do služenja narodu (European principles of public administration: From ruling to serving the people). Zagreb: Biblioteka Izazovi vremena.

Šokčević, Š., \& Dugalić, V. (2007). Privatisation of social/state ownership-(Un)successful transitional process. Diacovensia, $19(1), 103-154$.

Srića, V. (2013). Ta gadljiva politika (Disguisting politics). Zagreb: Profil.

Stefes, C. H. (2008). Governance, the state, and systemic corruption: Armenia and Georgia in comparison. Caucasian Review of International Affairs, 2(2), 73-83.

Stratmann, T. (2005). Some talk: Money in politics. A (partial) review of the literature. Public Choice, 124, 135-156.

Sung, H. E. (2004). Democracy and political corruption: A cross-national comparison. Crime, Law \& Social Change, 41, 179-194.

Županov, J. (1989). Self-managing socialism: The end of an Utopia. Croatian Political Science Review, 26(4), 21-36. 